\title{
Wader, gull and tern population estimates for a key breeding and stopover site in Central Kazakhstan
}

\author{
HOLGER SCHIELZETH, JOHANNES KAMP, GÖTZ EICHHORN, \\ THOMAS HEINICKE, MAXIM A. KOSHKIN, LARS LACHMANN, \\ ROBERT D. SHELDON and ALEXEJ V. KOSHKIN
}

\begin{abstract}
Summary
Population size estimates of waders, gulls and terns passing through or breeding in Central Asia are very scarce, although highly important for global flyway population estimates as well as for targeting local conservation efforts. The Tengiz-Korgalzhyn region is one of the largest wetland complexes in Central Asia. We conducted surveys in this region between 1999 and 2008 and present estimates of population size as well as information on phenology and age structure for 50 species of Charadriiformes. The Tengiz-Korgalzhyn wetlands are especially important for Rednecked Phalaropes Phalaropus lobatus and Ruffs Philomachus pugnax with, respectively, 41\% and $13 \%$ of their flyway populations using the area during spring migration. The region is also an important post-breeding moulting site for Pied Avocets Recurvirostra avosetta and Blacktailed Godwits Limosa limosa used by, respectively, 5\% and $4 \%$ of their flyway populations. Besides its key importance as a migratory stopover site, the study area is a key breeding site for the Critically Endangered Sociable Lapwing Vanellus gregarius, the Near Threatened Blackwinged Pratincole Glareola nordmanni and for Pallas's Gull Larus ichthyaetus with 16\%, 6\% and $5 \%$ of their world populations, respectively. We identified 29 individual sites that held more than $1 \%$ of the relevant flyway populations of at least one species of Charadriiformes. Including data on other species of waterbirds (mainly waterfowl), there were 93 sites that qualify for Important Bird Areas (IBA). About half of them are protected in a state nature reserve, while an additional $20 \%$ are recognised as IBAs. Nevertheless, 28 important sites are currently not recognised as IBAs nor are they protected by other conservation means. These sites require conservation attention.
\end{abstract}

\section{Introduction}

Siberian waders are mainly long-distance migrants, many of which follow the coastal flyways of Western Europe and Northern Africa, or migrate along the East Asian coasts (Veen et al. 2005, Davidson and Stroud 2006, Delany et al. 2009). Others migrate inland across Western Asia, and these can be assigned to three flyways: (a) the Black-Sea/Mediterranean flyway via Western Asia, Eastern Europe and the Caucasus region to the Mediterranean Basin and West Africa, (b) the West-Asian-East-African flyway via Central Asia to the Middle East, Southern Asia and Eastern Africa and (c) the Central Asian flyway via Central Asia to the Indian Subcontinent (Stroud et al. 2004, Delany et al. 2009). In Central Asia, there are relatively few wetlands that provide the opportunity for refuelling. One of the largest wetland complexes of Central Kazakhstan is situated in the Tengiz-Korgalzhyn region $\left(c \cdot 49 \cdot 5-51^{\circ} \mathrm{N}, 68-71^{\circ} \mathrm{E}\right)$. This region has been shown to hold large numbers of waterbirds (Krivitskii et al. 1985, Eichhorn 2001, Koshkin 
and Koshkina 2003, Gavrilov and Gavrilov 2005, Schielzeth et al. 2008), but comprehensive estimates of wader, gull and tern population sizes are still lacking.

Accurate estimates of bird numbers from individual wetlands are highly relevant for the implementation of wetland conservation programmes. They are needed to facilitate effective conservation of species of global concern and to prioritise local conservation efforts (Wetlands International 2006). To maximise conservation benefits, the development and maintenance of a network of refuelling sites along migration routes is required (Boere et al. 2006). Recognition of such sites under the Ramsar convention and as Important Bird Areas (IBAs) can provide valuable means of safeguarding key sites for waterbirds (Frazier 1999, BirdLife International 2001, Ramsar Convention Secretariat 2006). Both depend on sufficient information on the number of birds using particular sites. In Kazakhstan, a total of 121 IBAs have been identified recently, covering almost $150,000 \mathrm{~km}^{2}$, equivalent to $5.5 \%$ of the country area (Sklyarenko et al. 2008). Eight of these IBAs are situated in the Tengiz-Korgalzhyn region (Table 1 ). However, further data are needed to clarify if all the important wetlands are covered by the IBA network.

Here we provide recent population size estimates and phenology data for waders and larids (Charadiiformes) for the Tengiz-Korgalzhyn region. A list of potential IBAs for this region has been published previously (Schielzeth et al. 2008) but was based on other groups of waterbirds (mainly waterfowl). By expanding on waders and larids and including additional data from recent years, we update that former list and analyse how regularly individual sites hold significant numbers of waterbirds, in order to identify sites of high conservation priority in one of Central Asia's most important wetland complexes.

\section{Material and methods}

\section{Study area}

The study region encompasses an area of about $180 \times 150 \mathrm{~km}$ some $120 \mathrm{~km}$ southwest of the Kazakh capital Astana. The Korgalzhynskij zapovednik, a state nature reserve (IUCN category 1a), constitutes the core of the study area. It was extended in December 2008 to include not only the Lakes Bolshoi Tengiz, Malyi Tengiz and Lake Korgalzhyn, but also large areas of steppe habitats. The lakes of the zapovednik are registered as a Ramsar site ('Tengiz-Korgalzhyn Lake System', $2,589 \mathrm{~km}^{2}$, Sklyarenko et al. 2008) and since 2008 the zapovednik is part of the Saryarka World Heritage Site (UNESCO 2008). In addition to the zapovednik area itself, another seven IBAs have been identified in the Tengiz-Korgalzhyn area, totalling $837 \mathrm{~km}^{2}$ (Sklyarenko et al. 2008, Table I).

The region is characterized by pristine steppe grassland and dominated by the saline Lake Tengiz. It comprises a very large complex of saline and freshwater lakes. Due to low precipitation and high evaporation, lakes tend to shrink in size during summer and some dry up completely every year. Fluctuating water levels provide extensive areas of shallow water and large mudflats

Table 1. Important Bird Areas (IBA) in the Tengiz-Korgalzhyn region.

\begin{tabular}{|c|c|c|c|c|}
\hline Official name & IBA No & Area & Conservation status & Criteria \\
\hline Korgalzhyn State Nature Reserve & KZo51 & 258,963 ha & zapovednik & $\mathrm{A}_{1}, \mathrm{~A}_{3}, \mathrm{~A}_{4} \mathrm{i}, \mathrm{A}_{4} \mathrm{iii}$ \\
\hline Amangeldy & KZo52 & 5,536 ha & unprotected & $\mathrm{A}_{1}, \mathrm{~A}_{3}, \mathrm{~A}_{4} \mathrm{i}, \mathrm{A}_{4} \mathrm{iii}$ \\
\hline Zhumay-Mayshukyr Lake System & KZo53 & 12,490 ha & $\begin{array}{l}\text { largely unprotected } \\
\text { (but small part is } \\
\text { zapovednik) }\end{array}$ & $\mathrm{A}_{1}, \mathrm{~A}_{3}, \mathrm{~A}_{4} \mathrm{i}, \mathrm{A}_{4}$ iii \\
\hline Vicinity of Korgalzhyn village & KZo54 & 12,280 ha & unprotected & $\mathrm{A}_{1}, \mathrm{~A}_{3}, \mathrm{~A}_{4} \mathrm{i}, \mathrm{A}_{4} \mathrm{iii}$ \\
\hline Uyalyshalkar Lake System & KZo55 & 20,360 ha & unprotected & $\mathrm{A}_{1}, \mathrm{~A}_{3}, \mathrm{~A}_{4} \mathrm{i}, \mathrm{A}_{4} \mathrm{iii}$ \\
\hline Kumdykol-Zharlykol Lake System & KZo56 & 20,350 ha & unprotected & $\mathrm{A}_{1}, \mathrm{~A}_{3}, \mathrm{~A}_{4} \mathrm{i}, \mathrm{A}_{4} \mathrm{iii}$ \\
\hline Aktubek & KZo57 & 6,157 ha & unprotected & $\mathrm{A}_{1}, \mathrm{~A}_{3}, \mathrm{~A}_{4} \mathrm{i}$ \\
\hline Tuzashchy and Karasor Lake & KZo58 & 8,582 ha & unprotected & A1, A4i, A4iii \\
\hline
\end{tabular}


that are available to waders stopping over on migration. South of the Tengiz-Korgalzhyn region lies the extensive Betpak-dala semi-desert, a region lacking any significant areas of wetland. Hence, the Tengiz-Korgalzhyn wetland complex constitutes an important series of refuelling sites for waterbirds before (spring) or after (autumn) crossing this barrier.

\section{Survey methods}

Most of the data analysed here were collected together with data on other waterbird species analysed by Schielzeth et al. (2008), and we refer to that paper for a more detailed description of survey methods including maps showing the spatial-temporal distribution of survey counts in 1999-2004. However, by adding data from four more years, the present paper covers a study period of 10 years from 1999 to 2008. Surveys in 2005-2008 focussed more on spring, because this season had been less well covered in the years before. We also included results from dedicated surveys for two species of special conservation concern, Sociable Lapwing Vanellus gregarius (R.D. Sheldon and J. Kamp, unpubl. data) and Black-winged Pratincole Glareola nordmanni (Kamp et al. 2009). Both species were not sufficiently covered in our general wetland surveys, primarily because they are not confined to wetland habitats. The main focus of the survey work was to count the number of individuals, but for some species we made additional efforts to record the numbers of juveniles and adults separately.

\section{Calculation of local population sizes}

Estimates were calculated from counts at individual sites. The temporal resolution was set to monthly thirds (i.e. day $1-10,11-20$ and $21-30 / 31$ of each month). We analysed the data separately for the months April to mid-June ('spring') and end-June to October ('autumn'). This separates the year into approximately a pre-breeding and a post-breeding phase. Waders and larids vacate the area completely in winter (December to February) when all lakes are frozen. Numbers of waterbirds are generally very low in November and March.

As outlined in Schielzeth et al. (2008), we calculated two estimates of the local population for all species. Estimate one $\left(E s t_{1}\right)$ is the highest number of individuals counted within a monthly third in any of the ten years considered. It comprises summed data from different sites, assuming that changes in distributions within these 10-11 days are negligible. Estimate two $\left(E_{s} t_{2}\right)$ is the largest sum of average site counts (averaged between years) within a monthly third. This yields better coverage of the study region, since different parts of the study area were surveyed in different years. More formally, Est $t_{1}$ was calculated as the maximum of $N_{j k}$ with $N_{j k}$ calculated as

$$
N_{j k}=\sum_{i=1}^{n} c_{i j k}
$$

for every monthly third in every year, where $c_{i j k}$ is the count for site $i$ in year $j$ and monthly third $k$. Est $t_{2}$ was calculated as the maximum of $N_{k}$ with $N_{k}$ calculated as

$$
N_{k}=\sum_{i=1}^{n} a_{i k}
$$

for every species and every monthly third, where $a_{i k}$ is the number of birds at site $i$ in monthly third $k$ averaged from all years for which data were available. 
We present a final estimate in ranges of rounded figures between the two estimates $E_{s} t_{1}$ and Est $t_{2}$. Since we do not have any information on staging duration and migratory turn over, all estimates refer to peak staging numbers. True numbers of waders passing through during spring and autumn migration are certainly much higher. We rounded numbers below 100 to the nearest 5 , below 1,000 to the nearest 10 , below 10,000 to the nearest 100 and above 10,000 to the nearest 1,000. Non-zero estimates $<5$ were set to $0-5$.

To give an overview of the local wader and larid breeding fauna, we present the current breeding status for all species. Breeding surveys, however, were not the focus of the study.

\section{Comparison with flyway population estimates}

We compared our local population estimates to the estimates for the relevant flyway populations as published by Wetlands International (2006) and assigned flyway populations according to breeding and wintering ranges given therein. We considered populations that were covered either under 'Central Asia', 'SW Asia', 'W Asia' or 'Kazakhstan' or a combination of breeding grounds in 'Western Siberia' and wintering ground in 'East Africa', 'Middle East' or 'S Asia', since birds of these populations are likely to pass through the study area. Occasionally, more than one relevant flyway population had to be considered. In these cases we compared our estimates to the total of all relevant flyway estimates combined. We used mid-range values to calculate the proportion of the Tengiz-Korgalzhyn population relative to the total flyway population.

\section{Identification of key sites}

We identified individual sites within our study area that qualified as potential IBA and/or Ramsar sites. The relevant IBA criteria are: (A4i) the site supports more than $I \%$ of the flyway populations of a congregatory waterbird on a regular basis and (A4iii) the site supports more than 20,000 waterbirds of one or more species on a regular basis (Heath and Evans 2000). IBA criterion A4i is equivalent to Ramsar criterion 6, while IBA criterion A4iii is equivalent to Ramsar criterion 5 (Ramsar Convention Secretariat 2006). Since these criteria are not limited to Charadriiformes, we included data on other species of waterbirds (see Schielzeth et al. 2008, updated for the years 2005-2008). Besides criteria A4i and A4iii, criterion A1 (the occurrence of significant numbers of globally threatened species) is, among Charadriiformes, applicable for the 'Critically Endangered' Sociable Lapwing. However, detailed information on key breeding and staging sites of this species will be published elsewhere (R. D. Sheldon and J. Kamp, in prep.).

To determine if high numbers of waterbirds occur on a regular basis, we calculated the number of years, in which one of the criteria was fulfilled and the number of years in which a particular site was visited at a relevant time of the season. The latter was done by counting the number of years a site was visited in a monthly third for which the criterion was reached in at least one year. We consider sites that fulfilled at least one of the criteria in more than one year and in at least half the years of visits as fulfilling the criteria 'on a regular basis' and those that fulfilled the criteria in less than half of the years as 'irregular'. Sites that fulfilled the criteria in one year only (with one or two visits) were classified as 'data-deficient'.

\section{Results}

The Tengiz-Korgalzhyn region serves as an important stopover site for waders during the prebreeding as well as during the post-breeding migratory seasons (Tables 2 and 3 ). For many wader species (among them the most numerous ones, Red-necked Phalarope Phalaropus lobatus and Ruff Philomachus pugnax), numbers in spring were substantially higher than in autumn. The estimated total of waders, gulls and terns in the study area in spring amounted to 920,000$1,020,000$ birds while numbers in summer and autumn were substantially lower totalling 250,000-310,000 individuals. The general pattern of higher spring numbers in many species did not change when limiting the analysis to survey years 1999-2004. A number of species, however, occur mainly on post-breeding migration (Figure 1). 
Table 2. Estimated numbers of waders, gulls and terns in the Tengiz-Korgalzhyn region during spring (March to mid-June). See methods section for details on calculations; Est $=$ Estimate.

\begin{tabular}{|c|c|c|c|c|}
\hline Species & & Est $_{1} \max \left(N_{j k}\right)$ & $\mathrm{Est}_{2} \max \left(N_{k}\right)$ & Total estimate \\
\hline Eurasian Oystercatcher & Haematopus ostralegus & 7 & 9 & $5-10$ \\
\hline Black-winged Stilt & Himantopus himantopus & 423 & 456 & $420-460$ \\
\hline Pied Avocet & Recurvirostra avosetta & 600 & 626 & $600-630$ \\
\hline Black-winged Pratincole & Glareola nordmanni & 1,041 & 1,294 & $2,400^{a}$ \\
\hline Northern Lapwing & Vanellus vanellus & 288 & 361 & $290-360$ \\
\hline Sociable Lapwing & Vanellus gregarius & 417 & 765 & $420-770$ \\
\hline Eurasian Golden Plover & Pluvialis apricaria & 3 & 1 & $0-5$ \\
\hline Pacific Golden Plover & Pluvialis fulva & 2 & 1 & $0-5$ \\
\hline Grey Plover & Pluvialis squatarola & 244 & 262 & $240-260$ \\
\hline Common Ringed Plover & Charadrius hiaticula & 2,239 & 2,305 & $2,200-2,300$ \\
\hline Little Ringed Plover & Charadrius dubius & 49 & 80 & $50-80$ \\
\hline Kentish Plover & Charadrius alexandrinus & 51 & 54 & $50-55$ \\
\hline Caspian Plover & Charadrius asiaticus & 5 & 8 & $5-10$ \\
\hline Eurasian Dotterel & Charadrius morinellus & 1 & 1 & $0-5$ \\
\hline Common Snipe & Gallinago gallinago & 3 & 2 & $0-5$ \\
\hline Asian Dowitcher & Limnodromus semipalmatus & 2 & 2 & $0-5$ \\
\hline Black-tailed Godwit & Limosa limosa & 320 & 346 & $320-350$ \\
\hline Bar-tailed Godwit & Limosa lapponica & 5 & 3 & $0-5$ \\
\hline Whimbrel & Numenius phaeopus & 150 & 296 & $150-300$ \\
\hline Eurasian Curlew & Numenius arquata & 30 & 71 & $30-70$ \\
\hline Spotted Redshank & Tringa erythropus & 2,459 & 2,737 & $2,500-2,700$ \\
\hline Common Redshank & Tringa totanus & 150 & 186 & $150-190$ \\
\hline Marsh Sandpiper & Tringa stagnatilis & 148 & 149 & 150 \\
\hline Common Greenshank & Tringa nebularia & 105 & 123 & $110-120$ \\
\hline Green Sandpiper & Tringa ochropus & 6 & 11 & $5-10$ \\
\hline Wood Sandpiper & Tringa glareola & 280 & 545 & $280-550$ \\
\hline Terek Sandpiper & Xenus cinereus & 89 & 228 & $90-230$ \\
\hline Common Sandpiper & Actitis hypoleucos & 10 & 10 & 10 \\
\hline Ruddy Turnstone & Arenaria interpres & 16 & 22 & $15-20$ \\
\hline Sanderling & Calidris alba & 12 & 4 & $5-10$ \\
\hline Little Stint & Calidris minuta & 58,235 & 62,430 & $58,000-62,000$ \\
\hline Temminck's Stint & Calidris temminckii & 4,179 & 4,199 & 4,200 \\
\hline Curlew Sandpiper & Calidris ferruginea & 7,350 & 6,877 & $6,900-7,400$ \\
\hline Dunlin & Calidris alpina & 31,746 & 34,304 & $32,000-34,000$ \\
\hline Broad-billed Sandpiper & Limicola falcinellus & 1 & 1 & $0-5$ \\
\hline Ruff & Philomachus pugnax & 195,153 & 221,914 & $195,000-222,000$ \\
\hline Red-necked Phalarope & Phalaropus lobatus & 588,507 & 652,725 & $589,000-653,000$ \\
\hline Common Gull & Larus canus & 1,435 & 1,927 & $1,400-1,900$ \\
\hline Heuglin's Gull ${ }^{\mathrm{b}}$ & Larus (h.) heuglini & 7 & 7 & 5 \\
\hline Baraba Gull b & Larus (h.) barabensis & 1,513 & 1,567 & $2,200^{c}$ \\
\hline Pallas's Gull & Larus ichthyaetus & 2,854 & 3,660 & $2,900-3,700$ \\
\hline Black-headed Gull & Larus ridibundus & 6,110 & 6,110 & 6,100 \\
\hline Slender-billed Gull & Larus genei & 2,710 & 4,010 & $2,700-4,000$ \\
\hline Little Gull & Larus minutus & 169 & 225 & $170-230$ \\
\hline Gull-billed Tern & Gelochelidon nilotica & 1,201 & 1,207 & 1,200 \\
\hline Caspian Tern & Sterna caspia & 200 & 150 & $150-200$ \\
\hline Common Tern & Sterna hirundo & 248 & 343 & $250-340$ \\
\hline Little Tern & Sterna albifrons & 20 & 21 & 20 \\
\hline White-winged Tern & Chlidonias leucopterus & 11,647 & 11,177 & $11,000-12,000$ \\
\hline Black Tern & Chlidonias niger & 721 & 756 & $720-760$ \\
\hline
\end{tabular}

a Since the coverage was incomplete and a dedicated survey of the breeding population was conducted in 2006 (Kamp et al. 2009), we used twice the number of breeding pairs as an estimate for the spring population. 'Heuglin's Gull Larus heuglini heuglini and Baraba Gull Larus heuglini barabensis are recognised as conspecifics (under the name Heuglin's Gull Larus heuglini) in Wetlands International (2006), but are currently under taxonomic review by BirdLife International. Independent of the decision we treat them as separate taxa, since the Baraba Gull is a widespread breeding bird and Heuglin's Gull is a passage migrant in our study region, and both are identifiable in the field.

'In May-June 2000 we counted a total of at least 1,100 pairs. We used twice the number of breeding pairs as an estimate for the spring population. 
Table 3. Estimated numbers of waders, gulls and terns in the Tengiz-Korgalzhyn region during summer to autumn (end-June to November) and status of local breeding. See methods section for details on calculations; Est $=$ Estimate.

\begin{tabular}{|c|c|c|c|c|}
\hline Species & Breeding status & $\mathrm{Est}_{1} \max (\mathrm{Njk})$ & $\mathrm{Est}_{2} \max (\mathrm{Nk})$ & Total estimate \\
\hline Eurasian Oystercatcher & rare & 8 & 12 & 10 \\
\hline Black-winged Stilt & common & 575 & 559 & $560-580$ \\
\hline Pied Avocet & uncommon & 2,770 & 3,173 & $2,800-3,200$ \\
\hline Black-winged Pratincole & common & 1,168 & 1,440 & $1,200-1,400$ \\
\hline Northern Lapwing & common & 4,152 & 4,074 & $4,100-4,200$ \\
\hline Sociable Lapwing & uncommon & 836 & 1,525 & $840-1,530$ \\
\hline Eurasian Golden Plover & - & 12 & 4 & $5-10$ \\
\hline Pacific Golden Plover & - & 41 & 44 & $40-45$ \\
\hline Grey Plover & - & 794 & 732 & $730-790$ \\
\hline Common Ringed Plover & - & 477 & 882 & $480-880$ \\
\hline Little Ringed Plover & common & 73 & 119 & $75-120$ \\
\hline Kentish Plover & uncommon & 571 & 709 & $570-710$ \\
\hline Caspian Plover & rare & 188 & 188 & 190 \\
\hline Eurasian Dotterel & - & 127 & 137 & $130-140$ \\
\hline Common Snipe & - & 325 & 344 & $330-340$ \\
\hline Asian Dowitcher & 一 & 19 & 4 & $5-20$ \\
\hline Black-tailed Godwit & common & 8,056 & 11,481 & $8,100-11,500$ \\
\hline Bar-tailed Godwit & - & 51 & 53 & $50-55$ \\
\hline Whimbrel & - & 5 & 7 & 5 \\
\hline Eurasian Curlew & rare & 206 & 301 & $210-300$ \\
\hline Spotted Redshank & - & 200 & 306 & $200-310$ \\
\hline Common Redshank & common & 706 & 759 & $710-760$ \\
\hline Marsh Sandpiper & common & 310 & 430 & $310-430$ \\
\hline Common Greenshank & - & 35 & 72 & $35-70$ \\
\hline Green Sandpiper & - & 23 & 41 & $25-40$ \\
\hline Wood Sandpiper & - & 910 & 1,224 & $910-1,220$ \\
\hline Terek Sandpiper & - & 236 & 453 & $240-450$ \\
\hline Common Sandpiper & - & 15 & 30 & $15-30$ \\
\hline Ruddy Turnstone & - & 31 & 49 & $30-50$ \\
\hline Sanderling & - & 134 & 134 & 130 \\
\hline Little Stint & - & 13,175 & 17,535 & $13,000-18,000$ \\
\hline Temminck's Stint & - & 546 & 591 & $550-590$ \\
\hline Curlew Sandpiper & - & 2,100 & 2,277 & $2,100-2,300$ \\
\hline Dunlin & - & 3,923 & 4,661 & $3,900-4,700$ \\
\hline Broad-billed Sandpiper & - & 12 & 5 & $5-10$ \\
\hline Ruff & - & 11,521 & 24,764 & $12,000-25,000$ \\
\hline Red-necked Phalarope & - & 193,461 & 173,400 & $173,000-193,000$ \\
\hline Common Gull & common & 6,955 & 9,483 & $7,000-9,500$ \\
\hline Heuglin's Gull & - & 32 & 20 & $20-30$ \\
\hline Baraba Gull & common & 2,835 & 2,891 & $2,800-2,900$ \\
\hline Pallas's Gull & common & 609 & 564 & $560-610$ \\
\hline Black-headed Gull & common & 6,400 & 6,537 & $6,400-6,500$ \\
\hline Slender-billed Gull & uncommon & 3,143 & 3,171 & $3,100-3,200$ \\
\hline Little Gull & - & 155 & 155 & 160 \\
\hline Gull-billed Tern & uncommon & 2,497 & 2,467 & 2,500 \\
\hline Caspian Tern & uncommon & 337 & 409 & $340-410$ \\
\hline Common Tern & common & 2,285 & 2,323 & 2,300 \\
\hline Little Tern & uncommon & 319 & 435 & $320-440$ \\
\hline White-winged Tern & common & 3,311 & 3,858 & $3,300-3,900$ \\
\hline Black Tern & uncommon & 1,471 & 1,536 & 1,500 \\
\hline
\end{tabular}




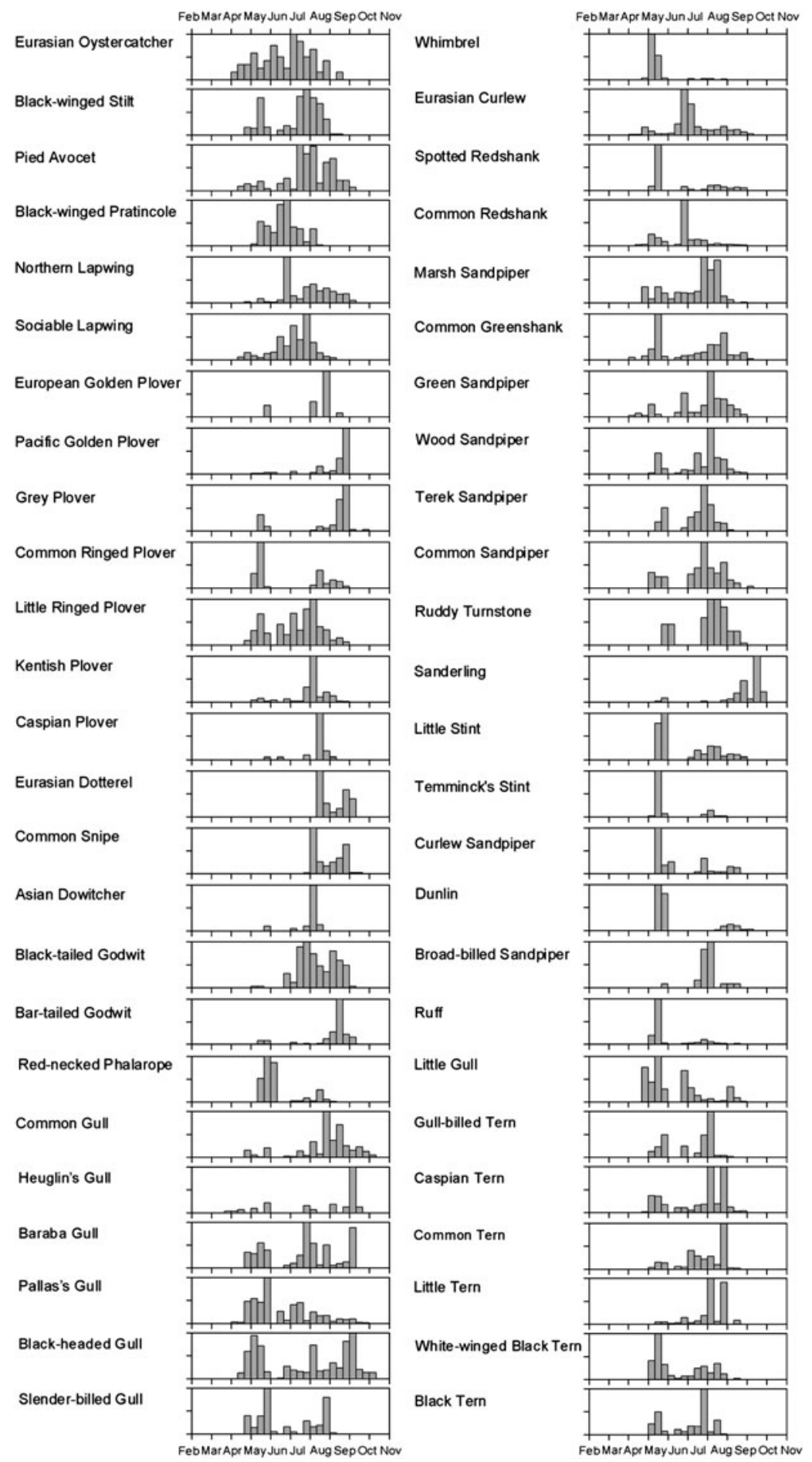

Figure 1 . Phenology of waders, gulls and terns in the Tengiz-Korgalzhyn region. For each species the value $N_{k}$ for any monthly third $k$ is given relative to the monthly third with the highest value $\max \left(N_{k}\right)(=E s t 2)$, i.e. for each species the maximum bar height is $100 \%$ (see methods for details on calculations). 
Most species for which sufficient data were available showed a high prevalence of adults in June/July and a strong dominance of juveniles in September/October (Figure 2). Notable exceptions were Pied Avocet Recurvirostra avosetta and Black-tailed Godwit Limosa limosa, for which adults dominated even in late summer. These two species show large moulting aggregations in the study region.

Based on a comparison with the total flyway population numbers, the Tengiz-Korgalzhyn region is of significant importance for Red-necked Phalaropes and Ruffs. These species were present in the area with $41 \%$ and $13 \%$, respectively, of their total flyway population estimates (Table 4). Dunlin Calidris alpina, Little Stint Calidris minuta, Spotted Redshank Tringa erythropus and Black-tailed Godwit (the latter classified as 'Near Threatened') occurred with about $5-6 \%$ of the their flyway population estimates, while other migrant species showed lower proportions. Pallas's Gull Larus ichthyaetus breeds with at least 1,715 pairs (data from 2000), which is equivalent to $5 \%$ of the individuals of the Central Asian population. Sociable Lapwing ('Critically Endangered') and Black-winged Pratincole ('Near Threatened') used the area in significant numbers as well, with up to $16 \%$ and $6 \%$, respectively, of their world populations.

There were 29 sites that held more than $1 \%$ of the flyway population for any species of Charadriiformes (excluding Sociable Lapwing). Including data on other species of waterbirds, we identified 93 individual sites that fulfilled IBA-criteria A4i and/or A4iii at least once during our study period (Figure 3, Table 5, Appendix). Forty-four (47\%) of these sites held high numbers of

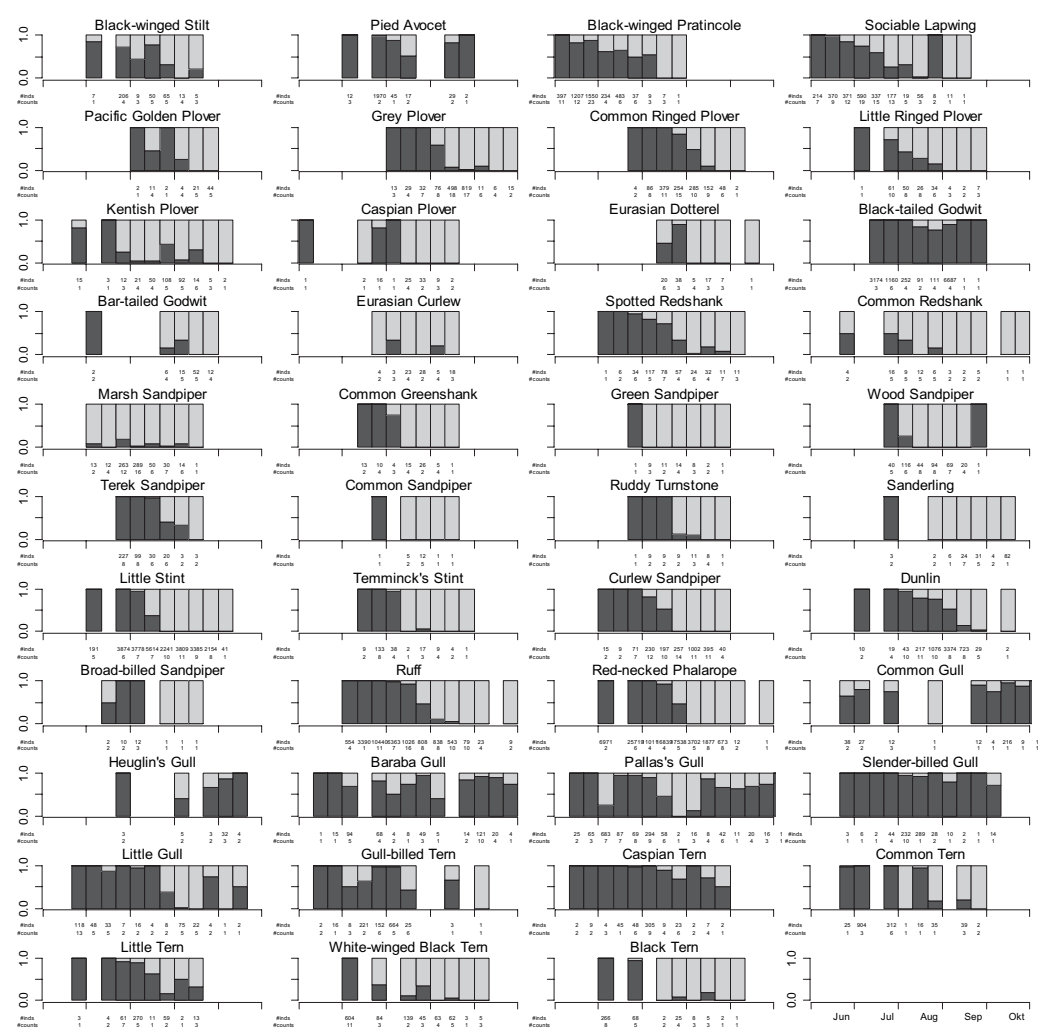

Figure 2. Proportion of adult ( $>_{1}$ year old, dark grey) and juvenile birds ( $>_{1}$ year, pale grey) in summer/autumn in the Tengiz-Kogalzhyn region. Proportions are based on sub-sampling with numbers of individuals and the number of flocks sampled given below the bars. 
Table 4. Comparison of the estimated peak staging populations of waders, gulls and terns in the Tengiz-Korgalzhyn region with flyway population estimates from Wetlands International (2006). Only species reaching more than $1 \%$ of the relevant flyway population in at least one season are listed. Numbers in the 'population' column refer to the sequence of populations (sequential numbering of rows) for the respective species as given in Wetlands International (2006). The significance level for the Tengiz region was calculated from the proportion of its population relative to the flyway population (using the mid-range value when a range of estimates is given). NT $=$ Near Threatened, $C R=$ Critically Endangered.

\begin{tabular}{|c|c|c|c|c|c|c|c|}
\hline \multirow[t]{2}{*}{ Species } & \multirow[t]{2}{*}{ IUCN status } & \multicolumn{3}{|l|}{ Flyway population } & \multirow[t]{2}{*}{ Tengiz population estimate } & \multicolumn{2}{|c|}{$\begin{array}{l}\text { Percent of flyway } \\
\text { population }\end{array}$} \\
\hline & & estimate & population & $1 \%$ criterion & & Spring & Autumn \\
\hline Red-necked Phalarope & & $1,000,000-2,000,000$ & 1 & 20,000 & $589,000-653,000$ & 41 & 12 \\
\hline Sociable Lapwing & CR & $3,400-11,200^{a}$ & $1,2^{\mathrm{a}}$ & $70^{\mathrm{a}}$ & $840-1,530$ & 8 & 16 \\
\hline Ruff & & $1,100,000-2,100,000$ & 2,3 & 20,000 & $195,000-222,000$ & 13 & 1 \\
\hline Little Stint & & $1,000,000$ & 2 & 10,000 & $58,000-62,000$ & 6 & 2 \\
\hline Black-winged Pratincole & NT & $29,000-45,000$ & 1 & 370 & 2,400 & 6 & 4 \\
\hline Dunlin & & 600,000 & 2,3 & 6,000 & $32,000-34,000$ & 6 & $<_{1}$ \\
\hline Pallas's Gull & & $25,000-100,000$ & 2 & 1,000 & $2,900-3,700$ & 5 & $<_{1}$ \\
\hline Spotted Redshank & & $10,000-100,000$ & 2 & 1,000 & $2,500-2,700$ & 5 & $<_{1}$ \\
\hline Black-tailed Godwit & NT & $175,000-250,000$ & 3,4 & 2,500 & $8,100-11,500$ & $<_{1}$ & 5 \\
\hline Pied Avocet & & $20,000-125,000$ & 5,6 & 1,250 & $2,800-3,200$ & $<_{1}$ & 4 \\
\hline Slender-billed Gull & & 150,000 & 3 & 1,500 & $2,700-4,000$ & 2 & 2 \\
\hline Little Tern & & $10,000-25,000$ & 3 & 250 & $320-440$ & $<_{1}$ & 2 \\
\hline Curlew Sandpiper & & 400,000 & 2 & 4,000 & $6,900-7,400$ & 2 & $<_{1}$ \\
\hline Gull-billed Tern & & $70,000-225,000$ & 3,4 & 1,050 & 2,500 & $<_{1}$ & 2 \\
\hline Black-winged Stilt & & $30,000-70,000$ & 6 & 500 & $580-560$ & $<_{1}$ & 1 \\
\hline
\end{tabular}

${ }^{\mathrm{a}}$ Estimate updated following Delany et al. 2009. 


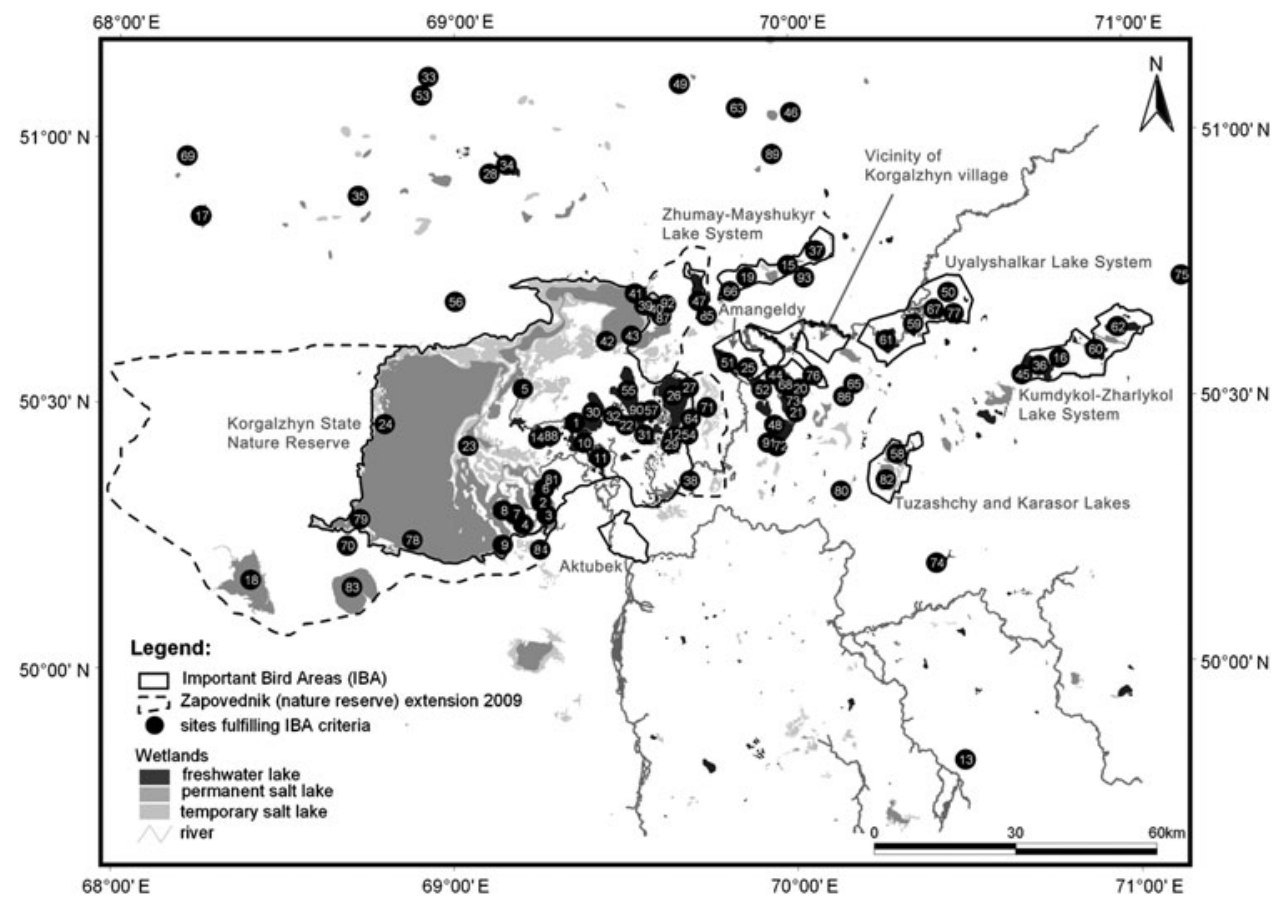

Figure 3. Individual sites that held more than 20,000 waterbirds or more than $1 \%$ of the flyway population for a particular species at least once in 1999-2008 (this study, Schielzeth et al. 2008). The black line shows the borders of the Important Bird Areas with their names printed in grey. The dashed line shows the borders of the zapovednik (state nature reserve). The numbering refers to the sequence of sites in the Appendix.

waterbirds on a regular basis, while $47(51 \%)$ have to be considered data-deficient for an assessment of regularity. Only two sites showed high numbers in less than $50 \%$ of all years of visits and are thus possibly of high importance for waterbirds only in some years.

\section{Discussion}

Our data show the outstanding importance of the Tengiz-Korgalzhyn wetlands for waders, gulls and terns. Ruff and Red-necked Phalarope in particular show very high absolute numbers as well as high proportions relative to the flyway population. Although numbers of most other species are lower than those of many species of waterfowl (Schielzeth et al. 2008) and comprise lower proportions of the relevant flyway populations, the region is an important staging and breeding site for many species of Charadriiformes. For some species, numbers were much higher in spring than in summer/autumn, which may be indicative of loop migration. In contrast, the phenology of waterfowl in the study area was biased towards the post-breeding period (Schielzeth et al. 2008).

The region's many water bodies of highly variable salinity produce a variety of benthic and epibenthic prey species principally available to waders. Larvae and pupae of alkali flies Ephydra sp. and long-legged flies Dolichopus sp. comprise most of the macrozoobenthos in saline lakes, while several species of Chironomidae larvae provide a rich food source in brackish and freshwater lakes (Eichhorn 2001). Although occurring more sporadically, mass concentrations of Brine Shrimp Artemia salina can attract huge numbers of waders, particularly phalaropes, to highly saline lakes and pools (Krivitskii et al. 1985). Most of these sites are of little interest to human exploitation and are left undisturbed. Power line casualties of Red-necked Phalaropes 
Table 5. Summary of potential IBA sites (criteria A4i and A4iii) in the Tengiz-Korgalzhyn region including Charadriiformes and other waterbirds (from Schielzeth et al. 2008). The status column gives the current protective status. Data quality 'regular' refers to sites that have been found to fulfil criteria more than once and in at least $50 \%$ of all visits during the peak migration period. Data quality 'data deficient' refers to sites that have been visited once or twice during the peak migration period, but have been found to fulfil the criteria only in one year. Data quality 'irregular' refers to sites that have been visited more than twice during the peak migration period, but fulfilled the criteria only once (i.e. less than $50 \%$ ).

\begin{tabular}{|c|c|c|c|c|c|}
\hline Data quality & Status & $\begin{array}{l}\text { Total \# } \\
\text { sites }\end{array}$ & $\begin{array}{l}\# \\
\text { sites } \\
\text { A4i (Charadriiformes) }\end{array}$ & $\begin{array}{l}\# \\
\text { sites } \\
\text { A4i (other waterbirds) }\end{array}$ & $\begin{array}{l}\text { \# sites } \\
\text { A4iii }\end{array}$ \\
\hline \multirow[t]{4}{*}{ Regular } & Zapovednik & 25 & 8 & 24 & 18 \\
\hline & IBA & 13 & 8 & 12 & 12 \\
\hline & partly IBA & 1 & 1 & 1 & 1 \\
\hline & no IBA & 5 & 1 & 5 & 2 \\
\hline \multirow[t]{3}{*}{ Data deficient } & Zapovednik & 20 & 5 & 15 & 4 \\
\hline & IBA & 5 & 1 & 4 & 2 \\
\hline & no IBA & 22 & 5 & 16 & 6 \\
\hline \multirow[t]{2}{*}{ Irregular } & Zapovednik & 1 & & 1 & \\
\hline & no IBA & 1 & & 1 & \\
\hline
\end{tabular}

have been noted (own observations), but power lines are relatively rare around lakes holding the highest numbers of waders.

The Tengiz-Korgalzhyn region was for a while one of the last known breeding sites of Sociable Lapwing (Eichhorn and Heinicke 2000, Eichhorn and Khrokov 2002), whose worldwide population had been estimated as low as 600-1,800 individuals (Wetlands International 2002). Extensive surveys from 2004 to 2008 suggested about 200 pairs currently breeding in the study area (R. D. Sheldon and J. Kamp, unpublished data). The new figures, together with data from other surveys in Kazakhstan have been used to update the world population estimate for this species to 5,600 breeding pairs, equalling 11,200 mature individuals (Sheldon et al. 2006).

The Black-winged Pratincole is another locally breeding wader species that has a stronghold in the Tengiz-Korgalzhyn region. A systematic survey of Black-winged Pratincole colonies has revealed c. 1,500 pairs in the Tengiz-Korgalzhyn region (Kamp et al. 2009). Both Sociable Lapwing and Black-winged Pratincole show a preference for heavily grazed steppe swards close to settlements. This makes trampling by livestock a potentially important cause of clutch loss (Watson et al. 2006). The same risk may apply to other species that prefer to nest in the surroundings of settlements (e.g. Caspian Plover Charadrius asiaticus, Northern Lapwing Vanellus vanellus).

Most gulls and Sterna terns, among them the Eurasian steppe biome-restricted Pallas's Gull, are colonial breeders in the Tengiz-Korgalzhyn region. Most of the known colonies are situated on islands of lakes outside the zapovednik but within IBAs. There does not seem to be any immediate danger for these colonies, although they should be considered vulnerable to disturbance. Breeding of Chlidonias terns occur over a much wider area and without dedicated surveys, complete coverage is difficult to achieve.

Including all species of waterbirds, we identified 93 individual sites that fulfilled IBA criteria A4i or A4iii (but see discussion on regularity below). These IBA criteria are equivalent to Ramsar criteria 6 and 5, respectively, meaning that these sites would potentially deserve Ramsar status, too. Although about half of these sites require more data to verify that the criteria are fulfilled on a regular basis, the great majority of sites that have been visited regularly hold significant wader and larid numbers on a regular basis, while only two sites were found to hold significant numbers in less than half of the years of visits (Table 5). Assuming that this sample is representative, it is very likely that most of the data-deficient sites fulfil the regularity condition. Not all potential Ramsar and/or IBA sites are currently protected. Forty-six sites (49\%) are situated within the 
protected zapovednik zone, while 19 (20\%) belong to IBAs outside the zapovednik (Figure 3, Table 5). The remaining 28 sites (30\%) have not yet been identified as IBAs or Ramsar sites nor do they enjoy any national status of protection. This shows that there is a need for further conservation efforts also outside the current IBA network.

Since our surveys were limited in coverage due to logistical limitations, we may have missed the peaks of migration for some species and sites. Hence, it is likely that some additional sites would fulfil criteria $\mathrm{A}_{4} \mathrm{i}$ or A4iii on a regular basis, if the survey data were more complete. Furthermore, due to varying water levels between seasons some individual sites may be best considered as subunits of larger sites, since waders may use shallow lakes in wet years but deeper lakes in dry years when shallow lakes dry out completely. Therefore, we advocate a designation of larger IBAs as was done during the recent designation of IBAs in Kazakhstan (Sklyarenko et al. 2008). However, since the current IBAs do not cover all relevant sites (Figures 3 and 4 ), we list all potentially relevant sites in the Appendix. Based on these data, we advise the designation of a new IBA southwest of Korgalzhyn, which could comprise a cluster of important sites (sites 20$21,44,48,52,65,68,72-73,76,86,91)$. Furthermore, it is necessary to consider the sites in the north of the region (particularly important for geese) as one or several additional IBA. Since only the zapovednik is considered a Ramsar site, but many important wetlands exist outside the zapovednik (Figure 3), an extension of this Ramsar site would also be advisable.

Overall, the Tengiz-Korgalzhyn region is of similar importance for migrating waders as it is for waterfowl. Although significant flyway proportions are reached by fewer species compared to waterfowl, the area is certainly one of the key stopover sites for northern-breeding waders on the Central Asian flyway. Moreover, the region hosts notable concentrations of species typically found in the steppe biome like Black-winged Pratincole ('Near Threatened'), Pied Avocet, Sociable Lapwing ('Critically Endangered'), Black-tailed Godwit ('Near Threatened'), Slenderbilled Gull Larus genei, Pallas's Gull and White-winged Tern Chlidonias leucopterus. We suggest this set of species along with the most abundant Nordic migrants (i.e. Red-necked Phalarope and Ruff) should be considered as the target species for the conservation of waders, gulls and terns in the Tengiz-Korgalzhyn region. To maximise conservation benefits, more sites should be considered for IBA status given the importance of the wetland complex to Charadriiformes and other waterbirds.

\section{Supplementary Material}

The supplementary materials for this article can be found at journals.cambridge.org/bci

\section{Acknowledgments}

We are grateful to Axel Bräunlich, Andreas J. Helbig, Dorit Liebers, Thomas Noah and Jörg Ratayczak for providing data and to Timur Iskakov, Tonya Grishina, Olga Koshkina and Gennadii Sidorin for their substantial logistical help. Surveys in 1999, 2000, 2002 and 2004 were funded by the ASA Program (administered by InWEnt), Naturschutzbund Deutschland (NABU) and the Royal Society for the Protection of Birds (RSPB). Surveys for Sociable Lapwing and Blackwinged Pratincole were part-funded by the UK government's Darwin Initiative and the Dutch 'Van der Hucht De Beukelaar Stichting'.

\section{References}

Birdlife International (2001) Important Bird Areas and potential Ramsar sites in Europe. Wageningen: BirdLife International.

Boere, G. C., Galbraith, C. A. and Stroud, D. A., eds. (2006) Waterbirds around the world: A global overview of the conserva- tion, management and research of the world's waterbird flyways. Edinburgh: The Stationery Office Ltd.

Davidson, N. C. and Stroud, D. A. (2006) African-Western Eurasian flyways: current knowledge, population status and future 
challenges. Pp. 63-73 in G. C. Boere, C. A. Galbraith and D. A. Stroud, eds. Waterbirds around the world. A global overview of the conservation, management and research of the world's waterbird flyways. Edinburgh: The Stationery Office Ltd.

Delany, S., Scott, D., Dodman, T. and Stroud, D., eds. (2009) An atlas of wader populations in Africa and western Eurasia. Wageningen: Wetlands International.

Eichhorn, G. (2001) Zur Bedeutung der Steppenseen Zentral-Kasachstans als Rastplatz arktischer Watvögel Charadrii, insbesondere zur Rastplatzökologie von Zwergstrandläufer Calidris minuta und Odinshühnchen Phalaropus lobatus. Diploma thesis, Johann Wolfgang GoetheUniversität, Frankfurt am Main.

Eichhorn, G. and Heinicke, T. (200o) Notable observations of the Sociable Plover Vanellus gregarius from the Tengiz-Korgalzhyn area, Central Kazakhstan. Wader Study Group Bull. 93: 73-76.

Eichhorn, G. and Khrokov, V. V. (2002) Decline in breeding Sociable Plover Chettusia gregaria in the steppes of Naurzum and Korgalzhyn, Kazakhstan. Sandgrouse 24: 22-27.

Frazier, S. (1999) Ramsar sites overview: A synopsis of the world's wetlands of international importance. Wageningen: Wetlands International.

Gavrilov, E. I. and Gavrilov, A. E. (2005) The birds of Kazakhstan. Almaty: Tethys.

Heath, M. F. and Evans, M. I. (2000) Important Bird Areas in Europe: Priority sites for conservation. Cambridge: BirdLife International.

Kamp, J., Koshkin, M. A. and Sheldon, R. D. (2009) Population size, breeding performance and habitat selection of the Blackwinged Pratincole Glareola nordmanni. Bird Conserv. Internatn. 19: 149-163.

Koshkin, A. V. and Koshkina, O. I. (2003) Kratkii obzor sostoyaniya krasnoknizhnykh vidov ptits $\mathrm{v}$ Tengizkom regione (Tsentralnyi Kazakhstan) [Short review of the status of Red Data Book bird species in the Tengiz region (Central Kazakhstan)]. Selevinia 11: 209-210.
Krivitskii, I. A., Khrokov, V. V., Volkov, E. N. and Zhulii, V. A. (1985) Ptitsy Kurgaldzhinskogo Zapovednika [Birds of the Kurgaldzhinskij Zapovednik]. Alma-Ata: Nauka.

Ramsar Convention Secretariat (2006) The Ramsar Convention manual: a guide to the Convention on Wetlands (Ramsar, Iran, 1971). 4th edn. Gland, Switzerland: Ramsar Convention Secretariat.

Schielzeth, H., Eichhorn, G., Heinecke, T., Kamp, J., Koshkin, M. A., Koshkin, A. V. and Lachmann, L. (2008) Waterbird population estimates for a key staging site in Kazakhstan: a contribution to wetland conservation on the Central Asian flyway. Bird Conserv. Internatn. 18: 71-86.

Sheldon, R. D., Grishina, V. A., Kamp, J., Khrokov, V. V., Knight, A. and Koshkin, M. A. 2006. Revising the breeding population estimate and distribution of the Critically Endangered Sociable Lapwing Vanellus gregarius. Wader Study Group Bull. 111: 30-31.

Sklyarenko, S. L., Welch, G. R. and Brombacher, M., eds. (2008) Important Bird Areas in Kazakhstan: priority sites for conservation. Almaty: Association for the Conservation of Biodiversity in Kazakhstan (ACBK).

Stroud, D. A., Davidson, N. C., West, R., Scott, D. A., Haanstra, L., Thorup, O., Ganter, B. and Delany, S., eds. (2004) Status of migratory wader populations in Africa and Western Eurasia in the 1990s. International Wader Studies 15: 1-259.

UNESCO (2008) Saryarka - Steppe and Lakes of Northern Kazakhstan. http://whc.unesco. org/en/list/1102, accessed 20 January 2010.

Veen, J., Yurlov, A. K., Delany, S. N., Mihantiev, A. I., Selivanova, M. A. and Boere, G. C. (2005) An atlas of movements of southwest Siberian waterbirds. Wageningen: Wetlands International.

Watson, M., Wilson, J. M., Koshkin, M., Sherbakov, B., Karpov, F., Gavrilov, A., Schielzeth, H., Brombacher, M., Collar, N. J. and Cresswell, W. (2006) Nest survival and productivity of the critically endangered Sociable Lapwing Vanellus gregarius. Ibis 148: 489-502. 
Wetlands International (2002) Waterbird population estimates - third edition. Wageningen: Wetlands International.
Wetlands International (2006) Waterbird population estimates - fourth edition. Wageningen: Wetlands International.

\section{HOLGER SCHIELZETH}

Max Planck Institute for Ornithology, Eberhard-Gwinner-Str. 5, 82319 Seewiesen, Germany, Current address: Uppsala University, Evolutionary Biology Center, Nobyvägen 18D, 75236 Uppsala, Sweden, holger.schielzeth@ebc.uu.se

\section{JOHANNES KAMP}

Royal Society for the Protection of Birds (RSPB), Conservation Science Dept., The Lodge, Sandy, Bedfordshire SG19 $2 D L, U K$

\section{GÖTZ EICHHORN}

Institut Pluridisciplinaire Hubert Curien, Département d'Ecologie, Physiologie et Ethologie, 20 CNRS, UdS, 23 rue Becquerel, 67087, Strasbourg cedex 02, France.

\section{THOMAS HEINICKE}

Chausseestr. 1, 18581 Vilmnitz, Germany

\section{MAXIM A. KOSHKIN}

Association for the Conservation of Biodiversity in Kazakhstan (ACBK), Off. 203, Orbita-1, 40, Almaty 050043, Republic of Kazakhstan

\section{LARS LACHMANN}

Royal Society for the Protection of Birds (RSPB), European Programmes Dept., The Lodge, Sandy, Bedfordshire SG19 2DL, UK

\section{ROBERT D. SHELDON}

Royal Society for the Protection of Birds (RSPB), RSPB Scotland Headquarters, Dunedin House, 25 Ravelston Terrace, Edinburgh $\mathrm{EH}_{4} 3 \mathrm{TP}, \mathrm{UK}$

\section{ALEXEJ V. KOSHKIN}

Korgalzhynskii Zapovednik, ul. M. Rakhimzhanova 20, p. Korgalzhyn 474210, Republic of Kazakhstan

Received 5 December 2008; revision accepted 15 May 2009;

Published online 9 March 2010 